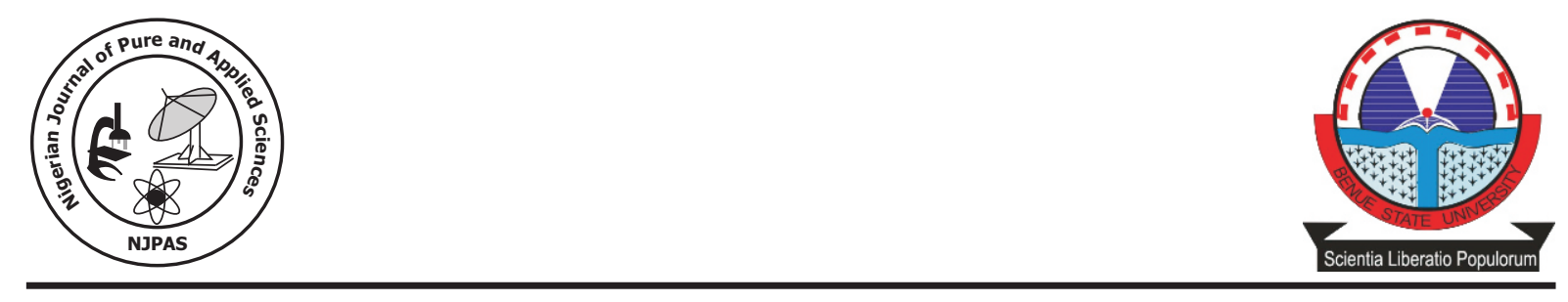

\title{
Microorganisms Associated with Post-Harvest Spoilage of Tomato (Lycopersicum esculentum) in Makurdi, Central Nigeria.
}

\author{
${ }^{1}$ Aernan, P.T *., ${ }^{2}$ Okoh, $\mathrm{T}$ and ${ }^{2}$ Adejo, O.E \\ ${ }^{1}$ Microbiology Unit, Department of Biological Sciences, \\ Federal University of Agriculture P M B 2373, Makurdi, Benue State, Nigeria. \\ ${ }^{2}$ Botany Unit, Department of Biological Sciences, Federal University of Agriculture, \\ P M B 2373, Makurdi, Benue State, Nigeria \\ Author for correspondence. E-mail: tracernan1@yahoo.com +2348053440971
}

\begin{abstract}
Microorganisms associated with post-harvest spoilage of tomato fruits in Makurdi were evaluated. Random sampling techniques were used to select 250 spoilt tomato fruits from North-bank, Wurukum, High level, Wadata and Modern markets. The bacteria isolated were Bacillus cereus, Bacillus subtillis, Esherichia coli and Staphylococcus aureus while isolated fungi included Aspergillusspp, Alternaria species, Rhizopusspp, Candida species and Fusarium species. The bacteria isolated, from the spoilt tomato fruits sampled from Wurukum market had the highest colony forming unit of $6.5 \times 10^{6}$ (CFU/ml) followed by the ones sampled from Wadata, High-level, North-bank and Modern markets having $5.8 \mathrm{x}$ $10^{6}(\mathrm{CFU} / \mathrm{ml}), 4.3 \times 10^{6}(\mathrm{CFU} / \mathrm{ml}), 4.3 \times 10^{6}(\mathrm{CFU} / \mathrm{ml})$, and $2.8 \times 10^{6}$ (CFU/ml) respectively. The fungi isolated from the spoilt tomato fruits from Wadata market had the highest colony forming unit of $6.7 \mathrm{x}$ $10^{7}$ (CFU/ml) followed by the samples from Wurukum, North-bank, High-level and Modern markets with $5.2 \times 10^{7}(\mathrm{CFU} / \mathrm{ml}), 4.6 \times 10^{7}(\mathrm{CFU} / \mathrm{ml}), 4.4 \times 10^{7}$ (CFU/ml) and $4.2 \times 10^{7}$ (CFU/ml) respectively.Using the same sampling techniques pathogenicity test on fifty (50) healthy tomato fruits from the same markets confirmed that bacteria and fungi that were earlier identified on the spoilt tomato fruits were still responsible for the spoilage, showing that deterioration of tomato fruits in Makurdi markets is due to the activities of these bacteria and fungi pathogens. Proper sanitary measures should be taken to improve harvesting and handling of tomato fruits to reduce spoilage caused by these pathogens.
\end{abstract}

Key words: Microorganisms, Tomato, Lycopersicum esculentum, Makurdi, Central Nigeria

\section{Introduction}

Tomato (Lycopersicum esculentum) fruits, often described as vegetable are a type of fleshy fruit characterized by its soft pulp, thin skin and many seeds (Anyanwu and Komolafe, 2003). On a worldwide scale, tomato continues to increase in importance for consumption as a fresh crop, as a major constituent in many prepared foods and also as materials for research into fundamental principles of growth and development in plantation (Ajayi and Olasehinde, 2009). Tomato fruits form an integral part of human diet. They provide basic food and nutritionally essential vitamins and trace elements. Moreover, it has an important role in improving food flavour and acceptability (Oladiran and Iwu, 1992). The fruits are used in a variety of ways either the raw or cooked state. Processing cultivars are used for 
production of purees, juices, canned fruits and sauces (Oladiran and Iwu, 1992). Tomatoes contain lycopene, one of nature's most powerful antioxidants. It is beneficial in fighting different kinds of diseases, most especially cancer (Zdenka et al., 2010).

Economically, tomato tops the list in value among edible vegetables (Anyanwu and Komolafe, 2003) and it is found in most cities of the world. Tomato fruits contain various minerals and vitamins. (Decuypere, 2006), its stability varies markedly as a function of environmental condition such as $\mathrm{PH}$ and concentration of trace metal ions and oxygen. Despite all the benefits that can be derived from tomatoes, a large percentage of tomatoes produced in Nigeria are being lost to postharvest deterioration caused by microorganisms (Ajayi and Olasehinde, 2009).

In Benue State, especially in Makurdi, tomatoes are planted between April and June with excess loss of fruits due to disease attack (Okoh, 2008). The growers of tomatoes therefore, need exact time of planting for high quality fruit and good yields. Inadequate storage facilities and shortage of processing industries contribute to loss of tomato fruit through the activities of microorganism. Larka (2004) reported the major pathogens isolated from tomato plant in Makurdi, Gboko, Buruku, and Tarka. These include Septora lycoperici from stem and fruit, Alternaria solani and Fusarium oxysporum isolated from all plant parts.

\section{Materials and Methods Sample Collection}

This study was carried out in Makurdi, the capital city of Benue State-Nigeria between June and September 2012.Tomato samples were collected from five (5) Market localities including; Wurukum market, Highlevel market, Wadata market Modern market and North-bank market.

A total of two hundred and fifty (250) Random rotted tomato fruits were collected from the markets afore mentioned. The samples were placed separately in a labeled sterile polythene bags and were transported immediately to the laboratory for culturing, isolation, identification and characterization of pathogenic microorganisms paying more attention on the diseased portion.

\section{Preparation of Samples for Examination}

The deteriorated tomato fruits were cut into $1-2 \mathrm{~cm}$ pieces with a sterile scalpel and $1 \mathrm{gm}$ of the sample was mixed with $9 \mathrm{ml}$ of distilled water and shaken properly. Using a fresh pipette at each stage, a serial dilution was carried out to $10^{-6}$ for bacteria and $10^{-7}$ for fungi dilution i.e. $1 \mathrm{ml}$ of the solution was drawn out using a pipette and was introduced into a second tube containing $9 \mathrm{ml}$ of distilled water and this was done serially until the last tube with $10^{-6}$ dilution was attained. The potato Dextrose Agar (PDA) and Nutrient Agar (NA) were melted and cooled. Sterile Petri dishes were set out for each pipette into the center of the appropriate dishes, using a fresh pipette for each dilution. Potato dextrose agar was poured into each of the plates. The above procedure was carried out on Nutrient Agar and potato Dextrose Agar. Plates were incubated at room temperature $\left(25^{\circ} \mathrm{C}\right)$ for two days. Total Colony Forming Units (CFU) in each plate were determined with a colony counter and expressed per $\mathrm{ml}$.

\section{Fungi Count}

Some colonies were stripped off using a sterile wire loop and placed on grease free glass slide. This set-up was stained using lacto phenol cotton blue, rinsed with sterile water and allowed to dry. A compound microscope with a magnification of x 100 was used to view the fungi morphologies and results were compared with standard charts which aided the identification as reported by (Obeta, Nwakonobi and Adikwu, 2011). The set up was monitored for five days, specifically for day 1, day 3and day 5 and results were recorded accordingly.

\section{Bacteriological Analysis}

Different types of bacteria isolates which grew on nutrient agar were streaked onto new nutrient agar using a loopful of the colonies on the previous nutrient agar. This 
was incubated at $37^{\circ} \mathrm{C}$ for 24 hours. Subculturing was done until pure cultures were obtained.

\section{Identification Tests}

Identification tests were done using the methods of Cowan and Stell (1974). These tests include Gram stain, Coagulase test, Catalase test, Sugar fermentation test, Spore formation test and Nitrate reduction test.

\section{Gram Reaction}

This reaction differentiates the Gram positive from the Gram negative bacteria due to differences in their cell wall structure.

A sterile wire loop was used to obtain a colony of the isolate on the plates and emulsified on a clean glass slide, it was smeared and air dried completely. The fixed smear was covered with crystal violet stains for $30-60$ seconds and rinsed with clean water. The smear was decolorized with acetone alcohol and flushed out with sterile clean water; the smear was then covered with neutral red stain for 2 minutes and rinsed with clean water. The back of the slide was wiped clean and allowed to air-dry after which the smear was examined microscopically, first with the X40 objective and the oil immersion objective to examine the bacteria.

\section{Catalase Test}

This test is used to differentiate those bacteria that produce the enzyme Catalase, such as Staphylococci from non-catalase producing bacteria such as Streptococci. A smear of the bacterium was made on a slide using sterilized wire loop. About 2 drops of $3 \%$ hydrogen peroxide was added onto the suspension on the slide. The production of gas bubbles indicates a positive reaction.

\section{Sugar Fermentation}

Sugar solution containing $1 \mathrm{~g}$ of glucose, fructose, lactose, sucrose and mannose were weighed. $100 \mathrm{ml}$ of peptone water, $0.05 \mathrm{~g}$ of phenol red was added serving as an indicator of acid production. $10 \mathrm{ml}$ of the medium each containing the different sugar was dispensed into test containing inverted Durham tubes to detect the presence of gas by the isolates. Each tubes of the different sugar were then incubated with the organism at $37^{\circ} \mathrm{C}$ for 24 to 28 hours.

\section{Spore Stain Test}

Smear were dried and fixed with minimal flaming on slides. The smears were flooded with $6 \%$ malachite green solution. These were later placed over a beaker of boiling water for 5 minutes and $0.5 \%$ safranin solution added and allowed for 3 seconds. The slides were afterwards rinsed in water, airdried and examined using oil immersion objective lens. Spores are stained green whereas the vegetative cells are stained red.

\section{Nitrate Reduction Test}

This test determines the ability of an organism to reduce nitrate to nitrites or free nitrogen gas using the enzyme nitrate reductase. For this test, $0.5 \mathrm{ml}$ of sterile nitrate broth was inoculated with a heavy growth of the test organism. Inoculation was done at $35-$ $37 \mathrm{oC}$ for 4 hours. I drop of sulphanilic acid and 1 drop of alpha-naphthylamine reagent was added, the mixture was shaken and observed.

\section{Pathogenicity Testing for Identification of Causative Organisms}

Fifty (50) healthy tomato fruits were randomly collected from the various markets localities mentioned before in Makurdi metropolis. A pathogenicity test was performed by wounding the fruits twice with a needle carrying one of the isolates. Each tomato was placed in a sealed container with a moist paper towel for one week and checked daily for lesions. This was repeated until all the isolates had been tested. Each lesion was reisolated from the tested tomato and compared to the Gram stain of the initial isolate. If they are the same, it means that they were causative organisms while those showing no lesions were referred to as non-pathogenic organisms. The descriptive and inferential analytical techniques as described by Umehet al (2007) and simple percentage were used. 


\section{Results}

A total of 250 tomato samples were collected from five (5) locations viz; Wurukum market, Modern market, High-level market, North-bank market, and Wadata market. In each location, fifty (50) samples were collected at random from three (3) strategic sites. A total of five (5) fungi species and four(4) Bacteria species were identified as shown in Table 1.

Table 1: Fungi and Bacteria species isolated and identified with respect to Locality.

\begin{tabular}{|c|c|c|c|c|c|c|}
\hline & $\begin{array}{l}\text { Wurukum } \\
\text { Market }\end{array}$ & $\begin{array}{l}\text { Modern } \\
\text { Market }\end{array}$ & $\begin{array}{l}\text { Wadata } \\
\text { Market }\end{array}$ & $\begin{array}{l}\text { High-level } \\
\text { Market }\end{array}$ & $\begin{array}{l}\text { North-Bank } \\
\text { Market }\end{array}$ & Total \\
\hline \multicolumn{7}{|l|}{ Fungi: } \\
\hline Aspergillusspp & 13 & 7 & 4 & 8 & 12 & $44(29.13)$ \\
\hline Alternariaspp & 7 & 9 & 10 & 4 & 8 & $38(25.10)$ \\
\hline Rhizopusspp & 9 & 6 & 4 & 5 & 6 & $30(19.86)$ \\
\hline Fusariumspp & 7 & 7 & 3 & 6 & 8 & $31(20.52)$ \\
\hline Candida spp & 2 & - & 6 & - & - & $8(5.2)$ \\
\hline $\begin{array}{l}\text { Total fungi found } \\
\text { Bacteria: }\end{array}$ & 38 & 29 & 27 & 23 & 34 & 151(100) \\
\hline Bacillus cereus & 7 & 4 & 3 & 2 & 2 & $18(15.3)$ \\
\hline Bacillus subtilis & 5 & 6 & - & 1 & 2 & $14(11.76)$ \\
\hline Escherichia coli & 23 & 10 & 6 & 6 & 9 & $54(45.37)$ \\
\hline Staphylococcus aureus & 12 & 8 & 3 & 4 & 6 & $33(27.73)$ \\
\hline Total bacteria found & 47 & 28 & 12 & 13 & 19 & $119(100)$ \\
\hline Total & 85 & 57 & 39 & 36 & 53 & 270 \\
\hline
\end{tabular}

Table 1is a representation of fungi and pathogenic bacteria species isolated and identified with respect to locations. Wurukum market has more pathogens than any other location, while high-level market has the least frequency of pathogenic organisms' occurrence. The frequency of occurrence of organisms in the Modern market and Northbank market is comparably higher than Wadata market although Wadata market seems to be significantly habouring Candida species.

Table 2: Percentage frequencies of microorganisms isolated from tomato

\begin{tabular}{ll}
\hline Parasite found & Frequency of occurrence and percentages (\%) \\
\hline Bacillus cereus & $18(7.2)$ \\
Bacillus subtilis & $14(5.6)$ \\
Escherichia coli & $54(21.6)$ \\
Staphylococcus aureus & $33(13.2)$ \\
Aspergillusspp & $44(17.6)$ \\
Alternariaspp & $38(15.2)$ \\
Rhizopusspp & $30(12.0)$ \\
Fusariumspp & $31(12.4)$ \\
Candida spp & $8(3.20)$ \\
Total microorganisms & 270 \\
\hline
\end{tabular}


The microorganisms isolated from the various localities are shown in Table 2. Escherichia coli (21.6\%), an indicator organism had the highest frequency of occurrence, followed by Aspergillusspp, $(17.6 \%)$, a fungus. The least associated organisms were Bacillus subtilis(5.6\%), and Candida species (3.2\%).

Table 3: Total fungi and bacterial counts

\begin{tabular}{lll}
\hline Description & Fungi colony forming units(cfu)/ml & bacteria(cfu)ml \\
\hline North bank market & $4.6 \times 10^{7}$ & $4.0 \times 10^{6}$ \\
Wurukum market & $5.2 \times 10^{7}$ & $6.5 \times 10^{6}$ \\
High level market & $4.4 \times 10^{7}$ & $4.3 \times 10^{6}$ \\
Wadata market & $6.7 \times 10^{7}$ & $5.8 \times 10^{6}$ \\
modern market & $4.2 \times 10^{7}$ & $2.8 \times 10^{6}$ \\
\hline
\end{tabular}

The presence of fungi and bacteria per $\mathrm{ml}$ of sample taken from each market site and their Colony Forming Units (CFU) after incubation are displayed in (Table 3). Wurukum market had the highest Colony Forming Units of $6.5 \times 10^{6}(\mathrm{CFU} / \mathrm{ml})$ while Modern market showed the lowest CFU of 2.8 $\mathrm{x} 10^{6}(\mathrm{CFU} / \mathrm{ml})$ for bacteria. The fungi isolated from the spoilt tomato fruits shows that Wadata market had the highest Colony Forming Units with $6.7 \times 10^{7}$ while Modern market recorded the lowest with $4.2 \times 10^{7}$ (CFU/ml).

\section{Discussion}

In this study the moulds Rhizopus species, Aspergillus species, Alternaria species. Fusarium species, and a yeast strain identified as Candida spp are found to be associated as important agents of tomato fruits. The bacteria identified in this study are Bacillus cereus, B. subtilis, Staphylococcus aureus and E. coli. Pathogenicity test carried out suggest that, the role of bacteria as tomato rot causing organisms is minimal since result shows no much difference from the test control.

This study collaborates with findings of George, Lucas and Leon (1992) and Larka, ( 2004 ) who demonstrated that microorganisms are primarily responsible for tomato deterioration. Also the findings of Chinoko and Nagvi (1989) affirms same, although they did not isolate Candida species. In their study. Candida species could be post harvest contaminants acquired probably during transportation from the farm to the market.

Total microbial count from the infected tomato fruits generally was high. This is an indication of unhygienic handling of tomato fruits either during harvesting or during transportation of the fruits from the farm to the market by careless and unsanitary handling of tomato by farmers.

Staphylococcus aureus was isolated from all the samples of tomato examined, it is a known micro flora of nostrils, skin and hands of man. It might have originated from the traders bodies or the contaminated air.

\section{Conclusion}

This study shows that microorganisms especially fungi cause deterioration in tomato and consumption of some of the infected tomato can cause disease in man. Some of these microorganisms are fungi while others are bacteria, making it almost impossible to keep them safe from infection without using chemicals that may be harmful to consumer. For instance, Bacillus species forms spores which can survive refrigeration.

The source of some of the common contaminating microorganisms which were isolated from tomato fruits could be from the farm during harvesting while others may be acquired as post-harvest contaminants probably during storage or in transit. Also the careless handling of these fruits by traders and consumers account for the major cause of tomato spoilage, this involves the use of direct River Benue water in washing and wetting of these fruits by Wurukum and Wadata markets traders. This can create a condition which predisposes the fruits to easy contamination. The use of dirty tables and rags used in covering tables increase the incidence of contamination. The use of dirty case and 
baskets for loading tomatoes and the pouring of these fruits on the floor as a way of preservation by the vendors lead to easy contamination of these tomato fruits.

Various market condition and varying environmental situation also increases rate of contamination of these fruits. For example, the closeness of tomato traders to refuse in Modern Market and Wadata market, the closeness of tomato vendors to gutter in Makurdi metropolis.

\section{Recommendations}

1. The presence of microorganisms on the surface of tomato fruits has an adverse effect on their shelf life. It is therefore advisable to surface sterilize tomato fruits after harvest or before consumption particularly if the fruits are to be eaten raw.

2. We also found in this study that wounds on the surface of tomato fruits can serve as portal of entry for these microbial pathogens. Better harvest practices to minimize cuts could help in reducing health hazards that might be associated with the consumption of raw tomatoes.

3. Tomatoes can be contaminated by certain decaying pathogens from contaminated air, insects and animals. It is important that packaging and storage areas be kept free of rodents, birds and insects which can disperse various undesirable microorganisms or even be the source of such organisms.

4. Thorough sorting of injured fruits is essential to minimize later development of post-harvest decays.

5. Baskets used for loading tomatoes should be inspected for cleanliness and where necessary should be cleaned and sanitized prior to loading.

6 Finally, good sanitary measures should be upheld from harvest through handling and distribution to consumers.

\section{References}

Ajayi A.A and Olasehinde I.G. (2009). Studies on the $\mathrm{PH}$ and protein contents of tomato (Lycopersicon esculentum Mill) fruits deteriorated by Aspergillus niger. Academic Journals of scientific Research and Essays. 4 (3): 185-187.

Anyanwu, C.O and Komolafe, B.T. (2003) Agricultural Science for schools and Colleges. Longman Publishers, Ibadan, Nigeria.

Chinko, Y.A and Naqvi, S.A. (1989). Studies on bacteria associated with post-harvest rot of tomato in South West Nigeria. Nigeria Journal of Botany. 2:9-17.

Cowam, S.T. and Stell, K., J. (1974). Manual for identification of medical bacterial, Revised second edition, Cambridge University, London U.K. 45-180.

George, B; Lucas, A; Lee, C. and Leon, T. (1992).Introduction to plant disease, identification and management. $2^{\text {nd }}$ ed. University press, U.S. 115-162.

Larka, B.S. (2004). Integrated approach for the management of soft rot (pectobacterituim carotovorum of radish seed crop). Argon. 20:128-129.

Mitchell, D.J. (1992). Morpgological and pathological characteristics of strains of colletotrichum gloeosporoides from citrus. Phytopathology. 88: 1377-1382.

Obetta, A.S; Nwakonobi, T.U. and Adikwu, O.A. (2011).Microbial effects on selected stored fruits and vegetables under ambient conditions in Makurdi, Benue, State, Nigeria. Research Journals of Applied Sciences, Engineering and Technology. 3(5): 393398.

Okoh, A.B. (2008).Effect of planting date on the yield of three tomato varieties in Makurdi. Undergraduate project research work. Department of crop production, University of Agriculture, Makurdi, Benue State, Nigeria. 410. 
Oladiran, A.O. and iwu, L.U (1992) Studies on the fungi associated with tomato fruit rots and effects of environment on storage. Mycopathology, 121:157-161.

Umeh, E. U; Ishaleka, D. and Iheukwumerem, C.C. (2007).HIV/Tuberculosis coinfection among patients attending Referral chest clinic in Nasarawa, Nigeria. Journal of Applied Sciences. 7, 933-935.
Walker, J.C. (1998). Bacterial rots of carrot. Discovery publishing house, New Delhi. 78.

Zdenka, P; Petr, S; Hana, D. and Milan, H. (2010).Antimutagenic effects of iycopen and tomato puree. Journal of medicinal food.3(6): A1443-1450. 